\title{
Scientific or Not? Mapping Category of Students' Written Argument
}

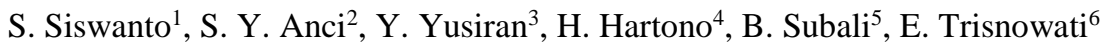 \\ \{siswanto@untidar.ac.id ${ }^{1}$,yulianci.syah@gmail.com ${ }^{2}$,yus_bima@yahoo.co.id ${ }^{3}$ \}

\begin{abstract}
Department of Natural Science Education, Universitas Tidar, Magelang, Indonesia ${ }^{1,6}$, Department of Primary Teacher of Education, STKIP Taman Siswa Bima, Bima, Indonesia ${ }^{2}$, Department of Physic Education, STKIP Bima, Bima, Indonesia ${ }^{3}$
\end{abstract}

\begin{abstract}
Argumentation skills have to be mastered and owned by students of the college. To investigate these, mapping the characteristics of students' written argument should be revealed. Therefore, this study aims to map how students' written arguments are categorized. Content analysis is a research method utilized in this study. Students' written argument of electricity and magnetism from 22 participants are analyzed. The analysis of mapping the written argument is divided into two parts. First, analysis is focused on considering argumentation components without scientific level. Finding the research portrays that level 2 (i.e. Data, Claim and or Warrant) dominates. Second, analysis is emphasized in argumentation components and scientific level of arguments. The result of research depicts that the category of Scientifically Unacceptable-Incorrect Scientific Knowledge (SU-2) is dominant. Its implication is a written argument should be taught to students comprehensively. Both components and scientific level of argument should be mastered by students.
\end{abstract}

Keywords: Argumentation Skills, Written Arguments, Scientific Level of Arguments

\section{Introduction}

Argumentation skills are an important thing in science learning, with no exceptions in learning physics [1]. Argumentation skills were importantly provided in physics learning because they are closely related to inquiry skills [2]. In addition, argumentation skills also facilitate students to develop their problem-solving skills [3]. On the other hand, argumentation skills also play an important role in building explanations, models, and theories from the learning concepts in order to facilitate students in terms of achieving concepts [4-6].

Inquiry and problem-solving skills are very necessary for students because learning science (physics) should not ignore the natural processes and products. Inquiry skills, problem-solving, and concept building through argumentation activities facilitate students to study science (physics) without ignoring the nature of science as a process and product. Therefore, direct argumentation skills facilitate students to learn how to built knowledge of science (physics). According to several research studies, the teaching and learning process in physics ideally has to provide argumentation skills to students [7],[8].

The importance of argumentation skills in accordance with several recent research. Some research suggests that the learning process in which practicing scientific argumentation activities can further enhance mastery concepts and maintain retention [4],[9],[10]. Through the 
argumentation activities, students become more skilled in expressing their arguments accompanied by the right reasons, so they will improve their cognitive abilities. The higher skill in constructing scientific arguments, knowledge construction ability will also be higher [4],[11].

Based on these exposures, argumentation skills are very important to be provided and mastered by students. Debriefing and training in argumentation skills can be done through the learning process. Lecturers must be able to compile a method and learning steps to effectively train argumentation skills to students because learning activities accompanied practice argumentation skills have special characteristics. In this case, not all learning activities can facilitate students to have argumentation skills.

The argumentation activities carried out to the Toulmin Argumentation Pattern [12], which includes 4 elements, namely: (1) Claims, are sentences directed to others to be accepted as truth; (2) Evidence (Data), is the truth of underlies claim in the form of reasoning so the claim cannot be contested anymore; (3) Justification (Warrant), is a sentence form which explains the relationship between a claim and the evidence presented; (4) Support (Backing), is an additional expression to support justification in the form of theory or fact.

Before compiling a learning activity in order to facilitate students to have argumentation skills, the studies must be carried out related to the ability of students to form arguments (argumentation skills). If it has been done, the lecturer can map the achievements of students' argumentation skills, which will later be related to the stages of the learning activities carried out. Therefore, this research will be conducted with the aim of mapping categories in student argumentation skills.

\section{Methods}

This research was conducted using the content analysis method. The analysis was carried out on student worksheet documents which were filled in student reports after conducting experimental activities. Experimental activities carried out by students are related to practical activities on electricity and magnetism. Student worksheets made by lecturers have analysis questions that are able to reveal how students arrange organs in arguing. The question: "Aldi wants to make an electrical circuit that requires a capacitor worth $75 \mu \mathrm{F}$. If Aldi has many capacitors but with a value of $100 \mu \mathrm{F}$, can Aldi make the electric circuit without having to buy new capacitors? Explain!".

Document analysis in revealing student argumentation skills is carried out in two categories. The first category is mapping students' argumentation skills by looking at the completeness of the organizing bodies of arguments, such as presenting claims, evidence, justification, and support. This category is student argumentation skills mapping without looking at the compiled scientific argumentation. In the second category, the mapping of students' argumentation skills is done by looking at the completeness and scholarship of the arguments prepared. Data grouping in the two categories refers to Table 1 and Table 2. Document analysis was carried out on 22 documents filled in by students. Examples of the argument's transcript prepared by students can be seen in Table 3. 
Table 1. Completeness Category of Argument Preparations.

\begin{tabular}{ll}
\hline Completion Level & Descriptions \\
\hline Level 1 & Claim only \\
Level 2 & Claim, data and/or warrant \\
Level 3 & Claim, data/warrant, backing or qualifier \\
Level 4 & Claim, data/warrant, backing, and qualifier \\
\hline
\end{tabular}

Table 2. Scientific Arranged Argument Category.

\begin{tabular}{ll}
\hline Scholarship Level & Descriptions \\
\hline SA1 (scientifically acceptable) & fully correct answer \\
SA2 (scientifically acceptable) & partially correct answer \\
SU1 (scientifically unacceptable) & irrelevant answer \\
SU2 (scientifically unacceptable) & incorrect scientific knowledge \\
NE (answer without explanation) & without explanation \\
\hline
\end{tabular}

Table 3. Example of Argument Transcripts Compiled by Students.

\begin{tabular}{|c|c|}
\hline \multicolumn{2}{|r|}{ Completion Category of Composes Arguments } \\
\hline Level & Examples \\
\hline Level 1 & $\begin{array}{l}\text { Yes, acceptable (claim). } \\
\text { Unacceptable (claim). }\end{array}$ \\
\hline Level 2 & $\begin{array}{l}\text { Yes, acceptable (claim). Use one capacitor } 100 \mu \mathrm{F} \text {, after it's filled } 75 \mu \mathrm{F} \text { disconnect } \\
\text { the circuit with power so that the capacitor is only filled with } 75 \mu \mathrm{F} \text { (warrant). }\end{array}$ \\
\hline Level 3 & $\begin{array}{l}\text { Yes, acceptable (claim). Each capacitor does have a value that characterizes its } \\
\text { capacitor (data). However, the capacitor value can be varied by combining several } \\
\text { capacitors in a series, series or parallel which can change the total capacitor value } \\
\text { (warrant). There are principles for calculating the total capacitor value of capacitors } \\
\text { arranged in series or in parallel (backing). }\end{array}$ \\
\hline \multicolumn{2}{|r|}{ Scientific Arguments Category } \\
\hline Level & Examples \\
\hline SA2 & $\begin{array}{l}\text { Yes, acceptable. Arrange the capacitor circuit in series, so that the capacitor value } \\
\text { becomes smaller. }\end{array}$ \\
\hline SU1 & $\begin{array}{l}\text { Yes, acceptable. Use one capacitor } 100 \mu \mathrm{F} \text {, after it's filled } 75 \mu \mathrm{F} \text { disconnects the } \\
\text { circuit with power so that the capacitor is only filled with } 75 \mu \mathrm{F} \text {. }\end{array}$ \\
\hline SU2 & $\begin{array}{l}\text { Yes, acceptable. A capacitor } 100 \mu \mathrm{F} \text { can be changed into } 75 \mu \mathrm{F} \text { by arranged it in } \\
\text { parallel because the electric charge that flows will be different (becomes smaller). }\end{array}$ \\
\hline $\mathrm{NE}$ & Yes, acceptable. \\
\hline & Unacceptable. \\
\hline
\end{tabular}




\section{Discussions}

Data of student's compile argument ability is obtained through analysis of documents in electrical and magnetic experimental reports. The obtained data are analyzed into two categories, named the completeness category in compiling arguments (organ composing arguments) and the scientific categories of the compiled arguments. The results of analyzing data about completeness in compiling arguments are shown in Figure 1.

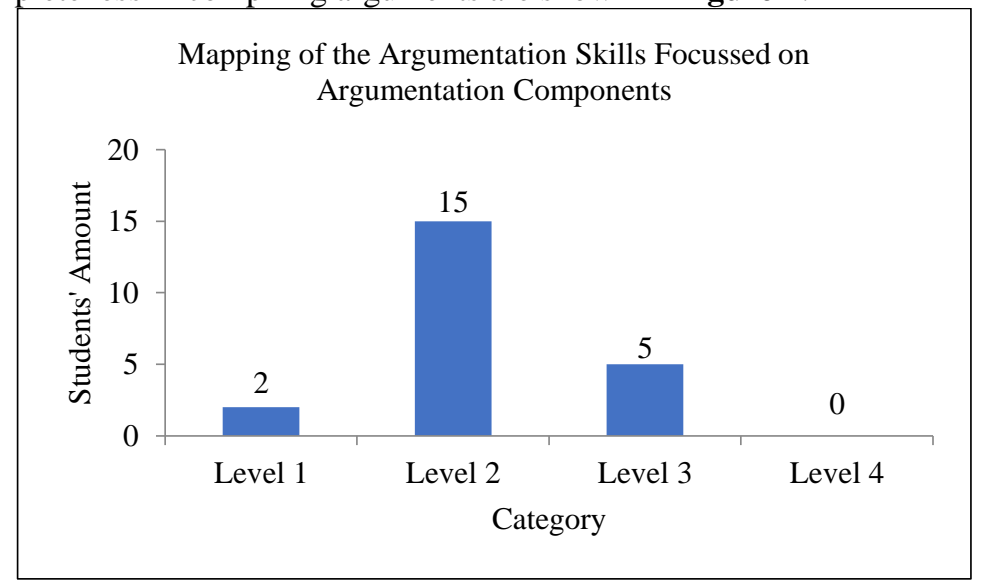

Fig. 1. Student's arranged arguments achievements based on completion component.

Based on Figure 1, it can be seen that the completeness level in compiling arguments varies. Completion argumentation varies at level 1 to level 3. The level of completeness in the argument preparation is at most 15 respondents at level 2, named the claims existence and reasoning explanation that accompanies them. The highest level that can be achieved by students is at level 3, namely the existence of claims, explanation of reasoning against the claims received, and support for the arguments raised.

Based on these data, students expressed more arguments about a concept without supporting backing data. Students are indeed quite difficult to compile a complete and systematic argumentation [13]. Integration in learning is needed to train to compile skilled for a complete organ argumentation [2-4]. The learning compiled process should facilitate students to practice submitting claims, data, warrant, backing/qualifier [8].

In addition, besides the organ's completeness, another important thing is the level of scientific knowledge prepared arguments. Data of the scientific argument categories prepared by students are shown in Figure 2. 


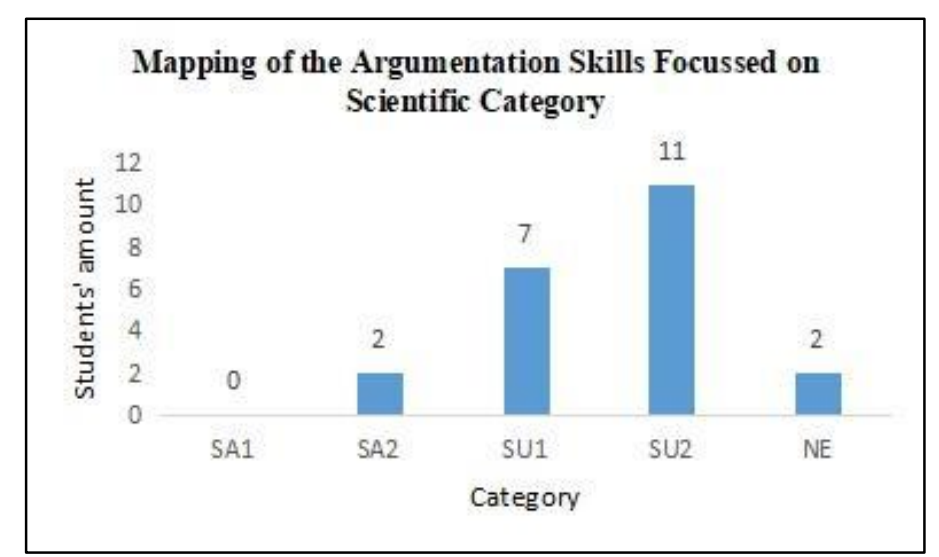

Fig. 2. Student's composes arguments achievement based on scientific level.

Based on Figure 2, there is no student able to compile an argument with a fully acceptable scientific level (SA1). There are only 2 students who are able to compile arguments with acceptable scientific categories with incomplete conceptualization (SA2). It is possible that students have not mastered the concept of material that has been thoroughly studied, so that when faced with a case that requires analysis. It is not able to explain the relationship between concepts correctly.

Most student's achievements, $50 \%$ of students are in the category of answers that are not conceptually correct so they cannot be acceptable scientifically (SU2). Based on data analysis, some of them still have misconceptions. In addition, this scientific inaccuracy due to the concept is not in accordance with the context of the material being discussed. Achievements in the SA2 and SU2 categories show that in general, these students have been able to compile arguments, even with an incomplete level of understanding.

Other scientific level categories named compiled arguments are not scientifically acceptable and it is not related between all the arguments compiled with the claims submitted. There are 7 students in this category (SU1). In addition to these achievements, there were also 2 students who only gave claims on a case, but did not provide an explanation. This category is the lowest category at the level of scientific scholarship given (NE).

The argument is indeed very closely related to the concept [4],[6],[10]. Therefore, in addition to training students for compiling arguments in accordance with their constituent organs, it is also necessary to train the degree of scholarship in compiling arguments. This is very important because argumentation helps students to further strengthen the learning concepts. The learning process in which students trained in science argument can build concepts and student reasoning about science [6],[13].

\section{Conclusions}

The findings in this study indicate that student achievement in compiling arguments needs to be improved and trained in the learning process, both in the category of organizing compilation completeness arguments, and the category of prepared scientific argumentation. 
Based on this finding, it was concluded that the ability of students to develop arguments was not maximal.

\section{References}

[1] Duschl, R.: Science Education in Three-Part Harmony: Balancing Conceptual, Epistemic, and Social Learning Goals. Review of Research in Education. Vol. 32, pp. 268-291 (2008)

[2] Kai Wu, H.: Developing Sixth Graders' Inquiry Skills to Construct Explanations in Inquiry-based Learning Environments. International Journal of Science Education.Vol. 28 (11), pp. 1289-1313. (2006)

[3] Cross, D., Taasoobshirazi, G., Hendricks, S., \& Hickey, D.: Argumentation: a Strategy for Improving Achievement and Revealing Scientific Identities. International Journal Of Science Education. Vol. 30 (6), pp. 837-861 (2008)

[4] Siswanto, Kaniawati, I. Suhandi, A.: Penerapan Model Pembelajaran Pembangkit Argumen Menggunakan Metode Saintifik untuk Meningkatkan Kemampuan Kognitif dan Keterampilan Berargumentasi Siswa. Jurnal Pendidikan Fisika Indonesia.Vol. 10 (2), pp. 104-116 (2014)

[5] Zohar, A., \& Nemet, F.: Fostering students knowledge and argumentation skills through dilemmas in human genetics. Journal of research in science teaching.Vol. 39 (1), pp. 3562 (2002)

[6] Siswanto et al. J. Phys.: Conf. Ser. 983012021 (2018)

[7] Osborne, J., Erduran, S. \& Simon, S.: Enhancing The Quality of Argumentation in School Science. Journal of Research in Science Teaching. Vol. 41 (10), pp. 994-1020 (2004)

[8] Kuhn.: Teaching and Learning Science as Argument. Wiley Periodicals, Inc. Sci Ed. Vol. (94), pp. 810-824 (2010)

[9] Mc. Neil, K. L., Lizotte, D. J., \& Karjcik, J.: Supporting Student's Construction of Scientific Explanations by Fading Scaffolds in Instructional Materials. The Journal of The Learning Science. Vol. 15 (2), pp. 153-191 (2006)

[10] Yusiran, Siswanto.: Implementasi Metode Saintifik Menggunakan Setting Argumentasi untuk Meningkatkan Kemampuan Kognitif. Jurnal Penelitian dan Pengembangan Pendidikan Fisika. Vol: 2(2), pp. 15-22 (2016)

[11] Erduran, S., \& Maria, P.: Argumentation in Science Education. Springer Science. London (2008)

[12] Toulmin, S.: The Uses of Argument. Cambridge University Press. New York (2003)

[13] Cetin, P. S.: Explicit argumentation instruction to facilitate conceptual understanding and argumentation skills, Research in Science \& Technological Education. Vol. 32 (1), pp. 1-20. (2014) 